\title{
PERTANGGUNGJAWABAN ADVOKAT SEBAGAI GATEKEEPER DALAM KAITANNYA DENGAN TINDAK PIDANA PENCUCIAN UANG
}

\author{
Rendy Ardy Septia Yuristara \\ rendyardysyshmh@gmail.com \\ Universitas Airlangga
}

\begin{abstract}
Advocates are the most vulnerable professions to be Gatekeepers in money laundering. Indeed, the advocate profession is part of the law enforcement apparatus that can contribute better in preventing money laundering activities to develop. Affirmation about the role of advocate that can suppress the occurrence of money laundering crime, that is with the issuance of PP. 43 of 2015, which places advocates as one of the reporting parties in the agenda of eradicating money laundering crime. However, the substance of the rule draws criticism from some misguided advocates in interpreting the intent and purpose of the arrangement. Moreover there are some advocates who consider that the rule is against the rules that regulate immunity rights in the profession advocate. The misinterpretation of some advocates related to the immunity rights inherent in the profession, causing the work of the advocate profession to be considered irrelevant, and not worthy of being called the nobleprofession (OfficiumNobile), But as a bad profession in integrity and promoting commercialization. In fact, the basic purpose of the arrangement of PP. 43 of 2015, which places the advocate profession as one of the reporting parties on the eradication agenda of money laundering, is a form of respect for the profession of advocate who is a noble profession, by prioritizing his professional responsibilities to the state, society and God, as well as his obligations as part of The legal profession to uphold the law and uphold the value of human rights while on duty.
\end{abstract}

Keywords: Advocate Profession; Gatekeeper; Money Laundering; Crime; Reporting Party.

\begin{abstract}
Abstrak
Advokat merupakan profesi yang paling rentan menjadi Gatekeeper dalam tindak pidana pencucian uang. Sesungguhnya profesi advokat merupakan bagian dari aparat penegak hukum yang dapat berkontribusi lebih baik dalam mencegah aktifitas pencucian uang untuk berkembang. Penegasan mengenai peran advokat yang dapat menekan terjadinya tindak pidana pencucian uang, yaitu dengan diterbitkannya PP No. 43 Tahun 2015, yang menempatkan advokat sebagai salah satu pihak pelapor dalam agenda pemberantasan tindak pidana pencucian uang. Namun, substansi dari peraturan tersebut menuai kritik dari sebagian advokat yang salah dalam mengintepretasi maksud dan tujuan pengaturan tersebut. Terlebih lagi ada sebagian advokat yang menilai bahwa peraturan tersebut bertentangan dengan peraturan yang mengatur hak imunitas pada profesi advokat. Misinterpretasi dari sebagian advokat terkait dengan hak imunitas yang melekat pada profesinya tersebut, menyebabkan hasil kerja dari profesi advokat dinilai tidak relevan, dan tidak pantas disebut sebagai profesi yang luhur (Officium Nobile), melainkan sebagai profesi yang buruk dalam integritas dan mengedepankan komersialisasi ntegritas dan mengedepankan komersialisasi. Sesungguhnya, tujuan dasardari pengaturan pada PP No. 43 Tahun 2015, yang menempatkan profesi advokat sebagai salah satu pihak pelapor dalam agenda pemberantasan tindak pidana pencucian uang, adalah suatu bentuk penghormatan terhadap profesi advokat yang merupakan profesi mulia, dengan mengedepankan tanggung jawab profesinya pada negara, masyarakat dan Tuhan, serta kewajibannya sebagai bagian dari profesi hukum untuk menegakkan hukum dan menjunjung tinggi nilai hak asasi manusia saat bertugas.
\end{abstract}

Kata Kunci: Profesi Advokat; Gatekeeper; Tindak Pidana Pencucian Uang; Pihak Pelapor. 


\section{Pendahuluan}

Pada tanggal 15 Desember 2000 di Palermo Italia, Indonesia sebagai negara anggota Perserikatan Bangsa-Bangsa (selanjutnya disebut dengan PBB) turut menandatangani United Nations Convention Against Transnational Organized Crime (Konvensi Perserikatan Bangsa-Bangsa Menentang Tindak Pidana Transnasional yang Terorganisasi). ${ }^{1}$ Pengesahan tersebut mulai berlaku di Indonesia sejak disahkan oleh presiden dan diundangkan oleh menteri hukum dan hak asasi manusia (selanjutnya disebut dengan MENKUMHAM) dalam suatu bentuk peraturan perundang-undangan. Peraturan perundang-undangan yang dimaksud diatas adalah Undang-Undang Nomor 5 Tahun 2009 Tentang Pengesahan Konvensi Perserikatan Bangsa-Bangsa Menentang Tindak Pidana Transnasional yang Terorganisasi (selanjutnya disebut dengan UU UNCATOC). Salah satu pasal dalam United Nations Convention Against Transnasional Organized Crime (selanjutnya disebut dengan UNCATOC), adalah Pasal 7 ayat 4 UNCATOC, yang pada isi pasal tersebut berbunyi: ${ }^{2}$ States Parties shall endeavour to develop and promote global, regional, subregional and bilateral cooperation among judicial, law enforcement and financial regulatory authorities in order to combat money-laundering. Terjemahan bebas dari pernyataan tersebut yaitu Negara Pihak wajib berupaya untuk mengembangkan dan meningkatkan kerjasama global, regional, sub-regional dan bilateral antara aparat peradilan, penegak hukum dan apparat pengatur keuangan guna memberantas tindak pidana pencucian uang. Pesan penting dari pernyataan tersebut yaitu, bahwa untuk setiap negara yang telah meratifikasi konvensi tersebut, wajib untuk melakukan suatu hubungan kerjasama yang kuat dalam memberantas tindak pidana pencucian uang. Melihat makna dari isi Pasal 7 ayat 4 UNCATOC tersebut maka dapat disimpulkan bahwa, tindak pidana pencucian uang merupakan suatu tindak pidana yang sifatnya serius, sehingga dalam penanganannya sangat diperlukan adanya perlakuan khusus

\footnotetext{
${ }^{1}$ Undang-Undang Nomor 5 Tahun 2009 Tentang Pengesahan United Nations Convention Against Transnasional Organized Crim.

${ }^{2} e$ (konvensi Perserikatan Bangsa-Bangsa Menentang Tindak Pidana Transnasional yang Terorganisasi), (Tambahan Lembaran Negara Republik Indonesia Nomor 4960). Penjelasan Umum United Nation Convention Against Transnasional Organized Crime, Pasal 7 ayat 4.
} 
terhadap tindak pidana tersebut. Misalnya membutuhkan adanya kerja sama yang baik antara aparat penegak hukum, membutuhkan dukungan dari ruang lingkup antar negara, dan kesadaran terhadap profesi yang rentan bersinggungan dengan aktifitas pencucian uang, untuk dapat memberikan kontribusi yang baik kepada pemerintah terkait pemberantasan tindak pidana pencucian uang. Sekian hal yang telah disebutkan tersebut semata-mata demi mencegah, dan memberantas tindak pidana pencucian uang secara maksimal.

Pencucian uang (Money Laundering) merupakan suatu fenomena global yang menjadi tantangan internasional. Money Laundering atau pencucian uang, adalah salah satu jenis kejahatan yang mendunia, dan merupakan bagian dari kejahatan yang terorganisir. ${ }^{3}$ Tindak pidana pencucian uang merupakan suatu tindak pidana lanjutan. Jadi, keberadaan tindak pidana pencucian uang selalu diawali dengan keberadaan tindak pidana asal (core crime). ${ }^{4}$ Dengan kata lain, dapat disimpulkan bahwa kejahatan money laundering merupakan tindak pidana ikutan (follow up crime/supplementary crime) yang sangatlah bergantung pada terjadinya tindak pidana asal (core crime). ${ }^{5}$ Sehingga, dalam upaya memberantas tindak pidana pencucian uang aparat penegak hukum juga perlu meningkatkan upaya pencegahan, dan pemberantasan terhadap tindak pidana asalnya juga. Tujuan dari upaya tersebut semata-mata adalah untuk meminimalisir terjadinya tindak pidana lanjutan (yang dimaksud adalah tindak pidana pencucian uang).

Menurut Barda Nawawi Arief, di Indonesia memiliki suatu kebijakan yang merupakan bentuk dari upaya untuk mencegah dan memberantas tindak pidana pencucian uang secara efektif. Kebijakan yang dimaksud adalah kebijakan legislatif/formulatif. Kebijakan legislatif/formulatif secara garis besar dibagi atas dua macam garis kebijakan yang salah satunya adalah kebijakan yang dituangkan dalam peraturan perundang-undangan dengan tindak pidana yang menjadi sumber

\footnotetext{
${ }^{3}$ M Arief Amrullah, 'Pencucian Uang Dan Kejahatan Terorganisir' (2003) 10 Jurnal Hukum.[1].

${ }^{4}$ Toetik Rahayuningsih, 'Perampasan Aset Hasil Tindak Pidana Perbankan Dalam Rangka Pemberantasan Tindak Pidana Pencucian Uang', Laporan Penelitian (2014). [3].

${ }^{5}$ Supriyadi Widodo Eddyono, Mengurai Implementasi Dan Tantangan Anti - Pencucian Uang Di Indonesia (ICJR (Institute for Criminal Justice Reform) 2015).[7].
} 
asal dari uang haram (dirty money), atau hasil kejahatan (Criminal Proceeds) yang kemudian dicuci. ${ }^{6}$ Hasil kejahatan yang dimaksud adalah harta kekayaan yang diperoleh dari tindak pidana asal. Macam-Macam tindak pidana asal yang terkait dengan tindak pidana pencucian uang tercantum pada Pasal 2 Undang-Undang Nomor 8 Tahun 2010 Tentang Pencegahan dan Pemberantasan Tindak Pidana Pencucian Uang (selanjutnya disebut UU No. 8/2010).

Proses untuk menyamarkan atau menyembunyikan harta kekayaan yang diperoleh dari berbagai macam tindak pidana asal, seperti macam-macam tindak pidana di atas, memiliki beberapa tahapan dengan masing-masing definisi yang berbeda. Maksud dari definisi terkait dengan masing-masing tahapan yang berbeda tersebut, menjelaskan tentang perbedaan tujuan dari masing-masing pelaku tindak pidana pencucian uang terkait dengan proses tindakannya. Jadi, sebenarnya ada beberapa tahapan dalam aktifitas tindak pidana pencucian uang, dan secara secara umum hanya diketahui terdapat tiga tahapan dalam kaitannya dengan tindak pidana tersebut, yaitu tahap penempatan, (placement), Transfer (layering), dan menggunakan harta kekayaan (integration).

Tahapan dalam pencucian uang yang dimaksud di atas, tentu tidak dapat dilaksanakan secara mandiri, jelas sangat dibutuhkan lebih dari satu orang demi menciptakan proses dalam suatu tindak pidana pencucian uang. Keikutsertaan atau deelneming, sulit untuk dipisahkan dari kasus tindak pidana pencucian uang. Deelneming atau penyertaan adalah suatu rangkaian kegiatan turut serta yang dilaksanakan lebih dari satu orang, dan setiap orang memiliki peran dan tanggung jawab yang berbeda dalam suatu peristiwa tertentu. Pengaturan mengenai penyertaan tercantum pada Pasal 55 dan Pasal 56 Kitab Undang-Undang Hukum Pidana (selanjutnya disebut dengan KUHP).

Peristiwa penyertaan dalam kasus tindak pidana pencucian uang, rentan terjadi pada para professional di bidang keuangan dan hukum, yang memiliki keahlian,

\footnotetext{
${ }^{6}$ Mathitha Ranti Hapsari P., 'Kebijakan Formulasi Hukum Pidana Dalam Undang - Undang Tindak Pidana Pencucian Uang (Money Laundering)', Tesis (Bidang Kajian Hukum dan Sistem Peradilan Pidana Program Magister Ilmu Hukum Universitas Diponegoro).[74-75].
} 
pengetahuan, dan akses khusus kepada sistem keuangan global. Para professional tersebut dengan keahlian dan perlindungan hukum atas profesi mereka, dapat dengan mudah melakukan tindak pidana pencucian uang dari hasil tindak pidana atau perolehan harta kekayaan yang ilegal dari para pelaku kriminal. Karena berdasarkan dari keahlian dan keuntungan dari jabatan para professional tersebut, tentu tidak menutup kemungkinan bagi para pelaku kriminal untuk menggunakan jasa dari para professional tersebut, untuk mempermudah pelaksanakan tindak pidana pencucian uang. Jabatan strategis dari para professional yang dimaksud salah satunya adalah profesi advokat. Profesi advokat paling rentan untuk dimanfaatkan oleh para pelaku kriminal dalam melaksanaan tindak pidana pencucian uang. Karena rentannya profesi advokat untuk dimanfaatkan para pelaku kriminal khususnya dalam melaksanakan tindak pidana pencucian uang, maka dibentuklah suatu regulasi yang menyatakan profesi advokat sebagai profesi yang wajib melakukan suatu pelaporan terkait adanya transaksi mencurigakan kepada PPATK. Regulasi yang mewajibkan advokat untuk melaporkan transaksi mencurigakan dimaksud adalah, PP No. 43 Tahun 2015.

Profesi advokat adalah salah satu profesi yang paling rentan menjadigatekeeper, karena profesi tersebut sangat kuat posisinya untuk membela diri atau pihak lain atau melindungi diri atau pihak lain. Hal - hal tersebut dijunjung tinggi demi perlindungan kerahasiaan informasi antara advokat dan klien serta kemandirian advokat dalam membela klien. Pengertian gatekeeper pada pembahasan yang dimaksud adalah, individu yang memberikan jasa untuk menyamarkan atau menyembunyikan perolehan hasil tindak pidana asal, dengan cara memasukkannya ke dalam suatu sistem keuangan, perusahaan, dan sistem lainnya, baik secara domestik maupun internasional. ${ }^{7}$ Peter Mc Namee mengatakan bahwa profesi yang dikategorikan sebagai gatekeeper, sering memanfaatkan peraturan tentang perlindungan kerahasiaan yang diberikan kepadanya, untuk melakukan suatu tindak pidana tertentu. Misalnya terkait dengan aturan kerahasiaan yang dimiliki oleh profesi advokat bersama dengan kliennya. Hal tersebut digunakan sebagai alat perlindungan untuk tidak dicurigai peran sertanya

\footnotetext{
${ }^{7}$ Paku Utama, Memahami Asset Recovery \& Gatekeeper, Jakarta, Indonesian Legal Roundtable (Indonesian Legal Roundtable 2013).[142].
} 
dalam suatu tindak pidana pencucian uang. ${ }^{8}$ Tidak hanya sebatas perihal kerahasiaan saja, advokat juga dilindungi dengan alasan tertentu yang dibenarkan sesuai dengan peraturan perundang-undangan yang berlaku. Perlindungan terhadap profesi advokat yang dimaksud tercantum pada Pasal 16 Undang-Undang Nomor 18 Tahun 2003 Tentang Advokat (selanjutnya disebut UU No. 18/2003) yang berbunyi: Advokat tidak dapat dituntut baik secara perdata maupun pidana dalam menjalankan tugas profesinya dengan iktikad baik untuk kepentingan pembelaan Klien dalam sidang pengadilan. Iktikad baik yang dimaksud pada Pasal 16 UU No. 18/2003 adalah menjalankan tugas profesi demi tegaknya suatu keadilan berdasarkan hukum dalam membela kepentingan kliennya. ${ }^{9}$

Profesi Advokat tidak mendapat perlindungan hanya dari Pasal 16 UU No. 18/2003 saja, masih ada ketentuan lain pada UU No. 18/2003 yang melindungi profesi advokat. Ketentuan lain yang dimaksud adalah Pasal 19 ayat 2 UU No. 18/2003 yang berbunyi: 2 Advokat berhak atas kerahasiaan hubungannya dengan Klien, termasuk perlindungan atas berkas dan dokumennya terhadap penyitaan atau pemeriksaan dan perlindungan terhadap penyadapan atas komunikasi elektronik Advokat. Ketentuan tersebut, memperkuat hubungan kemitraan dengan klien dan menutup kesempatan bagi aparat penegak hukum untuk melakukan penyelidikan, penyidikan atau penuntutan kepada advokat, yang menurut catatan strategis dari profesinya dapat dengan mudah memberikan sarana atau kesempatan bagi para pelaku kriminal (yang dimaksud adalah klien dari advokat) untuk menyembunyikan atau menyamarkan harta kekayaan hasil dari tindak pidana asal, atau dengan kata lain membantu klien untuk melakukan suatu tindak pidana pencucian uang.

Peraturan mengenai perlindungan yang diberikan UU No. 18/2003 kepada profesi advokat, untuk sebagian diantara para pemegang profesi advokat salah dalam memahaminya. Hal ini merupakan suatu misinterpretasi yang fatal bagi ahli hukum yang menyandang profesi sebagai advokat. Sehingga dalam penelitian ini akan diluruskan misinterpretasi tersebut ke dalam suatu p enjabaran yang

\footnotetext{
8 ibid.[141]

9 ibid.
} 
komprehensif. Berdasarkan uraian yang telah dijabarkan tersebut, dalam penelitian ini akan dikaji, diteliti lebih dalam perihal permasalahan yang telah diangkat tersebut. Upaya-upaya tersebut dilakukan demi mencapai suatu kesimpulan yang dapat meluruskan misinterpretasi pada permasalahan tersebut. Upaya-upaya yang dimaksud, dilaksanakan berdasarkan kajian akademik, dan dituangkan dalam karya ilmiah yang berwujud tesis dengan judul "Pertanggungjawaban Advokat Sebagai Gatekeeper dalam kaitannya dengan Tindak Pidana Pencucian Uang”.

\section{Perbuatan Advokat yang Dapat Dikualifikasikan Sebagai Gatekeeper}

Advokat merupakan salah satu profesi yang rentan untuk terlibat dalam suatu tindak pidana pencucian uang, dan penyebutan secara konsep pada penelitian ini posisinya sebagai seorang gatekeeper. Seperti halnya telah diketahui di awal pembahasan mengenai konsep dari gatekeeper, maka advokat merupakan agen yang terkait di dalam suatu kegiatan ilegal yang termasuk ke dalam suatu aktifitas transaksi mencurigakan, dapat sebagai penganjur, turut serta, atau hanya sebatas sarana pembantu. Jadi, penyebutan agen dalam pernyataan tersebut, merupakan penjelasan terhadap advokat yang melakukan suatu rangkaian tindakan ilegal, yang dengan tujuannya untuk memudahkan kliennya dalam melakukan suatu proses pencucian uang, baik dalam menyembunyikan, mengelola, atau menyamarkan hasil perolehan tindak pidana dari kliennya. Beberapa kegiatan tersebut dapat berlangsung hingga pada fase mewujudkan, atau membentuk suatu aset dan selubung bisnis yang terlihat sah di mata hukum.

Rangkaian kegiatan yang dilakukan di atas, tidak hanya dapat dilakukan oleh profesi advokat saja. Pada dasarnya rangkaian kegiatan tersebut dapat dilakukan juga oleh beberapa profesi tertentu lainnya. Profesi tertentu lainnya yang dimaksud tersebut, adalah: These individuals and institutions are frequently bankers, corporate service providers (CSPS), trust companies, lawyers, accountants or 
other organisations which have access to the financial system. ${ }^{10}$ Jadi pada dasarnya, pelaku kejahatan yang ingin melakukan tindak pidana pencucian uang, biasanya memanfaatkan profesi advokat, notaris, akuntan, dan perencana keuangan, untuk melakukan tindak pidana pencucian uang. Hal tersebut dikarenakan para professional dimaksud, dinilai dapat menyamarkan hasil tindak pidana asal dengan mudah, bahkan tanpa terdeteksi oleh aparat penegak hukum. Para professional tersebut, merupakan para professional yang karena profesinya dinilai dapat membantu aktifitas pencucian uang dengan mudah. Sehingga banyak dari professional tersebut, rentan terlibat dalam selubung bisnis kotor yang diciptakan bersama dengan pelaku kejahatan. Para professional tersebut dikenal sebutannya sebagai gatekeeper, dan posisinya sangat penting dalam aktifitas pencucian uang. Dari sekian profesi yang telah disebutkan tersebut, agar sesuai dengan judul dari penelitian ini, maka hanya akan menempatkan posisi gatekeeper pada satu profesi saja, yaitu kepada profesi advokat.

Profesi advokat merupakan salah satu dari sekian banyak profesi yang sangat rentan terlibat dalam aktifitas pencucian uang. Karena profesi advokat, memiliki ruang gerak yang luas dalam melakukan segala aktifitas untuk kliennya. Misalnya, profesi advokat dapat memanfaatkan ilmu pengetahuannya, serta jaringan yang ia miliki untuk melakukan tindak pidana pencucian uang dengan mudah. Halhal tersebut yang menjadikan profesi advokat sebagai kuda hitam dalam aktifitas pencucian uang. Para pelaku pencucian uang di indonesia, yang melibatkan pekerja birokrasi seperti aparatur sipil negara yang korup dan pelaku tindak pidana pada umumnya, akan merasa khawatir jika teridentifikasi transaksinya oleh penyedia jasa keuangan. Oleh karenanya, salah satu modus operandi tindak pidana pencucian uang adalah menggunakan jasa dari profesi advokat sebagai gatekeeper. ${ }^{11}$

Profesi advokat merupakan profesi yang rentan terlibat dalam aktifitas pencucianuang, sebabdalamaturanhukummengenaiprofesinya, diberiperlindungan

10 Recovery, 'International Centre for Asset. Tracing Stolen Assets: A Practitioner's Handbook, Basel Institute on Governance', Makalah (International Centre for Asset Recovery Steinenring 2009).[82].

${ }^{11}$ Keuangan, 'Pusat Pelaporan Dan Analisis Transaksi', Laporan Tahunan 2014 (PPATK (Pusat Pelaporan dan Analisis Transaksi Keuangan) 2015).[19]. 
dalam segala aktifitas yang berhubungan dengan klien dan profesinya. Namun patut untuk dipahami bahwa, terkait dengan perlindungan pada profesi advokat hanya berlaku pada professional advokat yang menjunjung tinggi prinsip iktikad baik, dan kinerja yang tidak menyalahi aturan hukum lainnya. Profesi advokat pada hakikatnya merupakan profesi yang mulia dan terhormat (officiumnobile), serta sangat penting bagi para pencari keadilan yang membutuhkan jasa bantuan hukum. Bantuan hokum oleh advokat tidak saja terhadap klien yang tergolong orang - orang kaya saja, tetapi juga terhadap klien yang tidak mampu (miskin). ${ }^{12}$ Namun dewasa ini, profesi advokat menuai kritik dan cela dari masyarakat, yang dikarenakan sebagian advokat kurang menjunjung tinggi nilai - nilai luhur saat menjalankan profesinya. Lahirnya penilaian miring dari masyarakat tersebut, berdasarkan cerminan dari sebagian profesi advokat yang terlibat masalah dalam suatu kasus tindak pidana.

Advokat yang menjual kebenaran, menghalalkan segala cara, menodai etika profesi, dan merendahkan martabat advokat untuk kepentingannya sendiri dengan cara yang tidak halal, merupakan tindakan yang memprihatinkan bagi profesi advokat. Karena pada dasarnya, profesi advokat merupakan merupakan profesi yang luhur, dan mulia (officium nobille). ${ }^{13}$

Para advokat yang melakukan suatu hubungan kerjasama ilegal, terkait dengan turut serta bahkan sebagai penganjur dalam suatu tindak pidana pencucian uang (sesuai dengan judul penelitian ini) telah melanggar salah satu poin kewajiban yang melekat pada dirinya yaitu, kewajiban untuk menegakkan hukum termasuk supremasi hukum dan hak asasi manusia. Sebab, profesi advokat merupakan bagian dari aparat penegak hukum yang seharusnya mendukung, dan menjaga supremasi hukum, bukan sebaliknya, turut menodai supremasi hukum serta ikut bekerjasama dalam melakukan tindak pidana pencucian uang. Kemudian terkait dengan menegakkan hak asasi manusia, perlu dipahami oleh para penyandang profesi advokat, bahwa

\footnotetext{
${ }^{12}$ Agus Nurudin, 'Revitalisasi Keberpihakkan Profesi Advokat Terhadap Klien Yang Tidak Mampu’, Makalah (Kantor Konsultasi Hukum Agus Nurudin).[1].

${ }^{13}$ T Gayus Lumbun, 'Peran Advokat Sebagai Penegak Hukum Menghadapai Transnational Crimes Di Era Globalisasi’ (2004) IV No. 1 Law Review Fakultas Hukum Universitas Pelita Harapan.
} 
akibat yang ditimbulkan oleh suatu tidak pidana pencucian uang sangat merugikan masyarakat secara tidak langsung, meskipun tindak pidana pencucian uang tidak terlihat menimbulkan dampak yang signifikan pada bangsa dan negara, perlu diketahui bahwa, terkait dengan sebagian dana ilegal dari tindak pidana, (misalnya tindak pidana korupsi) yang kemudian dilakukan pengaburan terhadap hasil tindak pidana tersebut, merupakan suatu upaya yang menghambat lajur dari perencanaan pembangunan pada suatu negara. Pembahasan berikutnya adalah, resiko yang timbul dari misinterpretasi para advokat terkait dengan hak imunitas. Hak imunitas adalah kebebasan advokat untuk melakukan atau tidak melakukan setiap tindakan, atau mengeluarkan atau tidak mengeluarkan pendapat, keterangan atau dokumen kepada siapapun dalam melaksanakan tugasnya, sehingga advokat tersebut tidak dapat dihukum dalam melaksanakan tugasnya. ${ }^{14}$

Para advokat mendasarkan hak imunitas dengan merujuk pada pasal 16 dan Pasal 19 ayat 2 UU No. 18/2003. Dari kedua ketentuan tersebut, sebagian penyandang profesi advokat salah memahami isi pada aturan tersebut. Jadi, untuk sebagian advokat yang salah memahami isi dari ketentuan tersebut, menganggap profesinya merupakan profesi yang kebal hukum, sehingga dari pehaman ini menjadi hal yang dimanfaatkan oleh sebagian profesi advokat untuk berlindung dalam aturan hukum terkait dengan profesinya. Bagi para advokat yang meyakini hal tersebut, menjadikan diri mereka sebagai pribadi yang acuh akan resiko tuduhan terhadap suatu aktifitas tindak pidana. Terutama tuduhan mengenai aktifitas tindak pidana, yang dilakukan bersama dengan kliennya.

Salah satu contoh praktik pidana, yang dilandasi dengan cara kerjasama, dan dilakukan oleh advokat bersama dengan kliennya adalah praktik tindak pidana pencucian uang. Profesi advokat merupakan profesi yang rentan dimanfaatkan oleh pelaku tindak pidana untuk menjalankan aktifitas pencucian uang, karena profesi advokat dipandang strategis dari segi profesinya, dengan adanya peraturan yang melindungi profesinya diimbangi dengan keilmuan, 
dan koneksinya. Profesi advokat diyakini oleh para kriminal sebagai profesi yang baik dalam menyamarkan asal-usul harta kekayaan dari hasil suatu tindak pidana secara maksimal. Keyakinan tersebut timbul dikarenakan adanya, segala keuntungan yang melekat pada profesi advokat, sehingga para pelaku kejahatan sering memanfaatkan profesi advokat sebagai sarana dalam aktifitas pencucian uang, dengan maksud untuk meminimalisir akan resiko terdeteksi oleh aparat penegak hukum dari segala aktifitas pencucian uang.

Jasa dan peran serta advokat bagi para kriminal, merupakan hal yang sangat penting ketika ingin melakukan suatu tindak pidana pencucian uang. Pernyataan tersebut berdasarkan dengan adanya alasan yaitu, tidak mudahnya dilakukan pelacakan oleh aparat penegak hukum terkait aset yang telah dicuci oleh advokat. Hal tersebut dapat terjadi, karena profesi advokat merupakan bagian dari salah satu profesi hukum yang juga mengenal kerja sistim dari aparat penegak hukum lainnya, sehingga mampu mengantisipasi resiko pergerakan dari aparat penegak hukum dalam hal penelusuran hingga aktifitas penindakan terhadap suatu praktik tindak pidana pencucian uang.

Pernyataan di atas mencerminan bahwa, profesi advokat merupakan suatu profesi yang sangat rawan berhubungan dengan aktifitas pencucian uang, karena dinilai sebagai profesi yang tepat untuk dimanfaatkan oleh para kriminal dalam hal melakukan tindak pidana pencucian uang. Di samping itu, kegiatan yang dilakukan oleh advokat dalam memberi bantuan jasa hukum kepada kliennya, dapat bersifat litigasi maupun non litigasi. Sehingga dapat dikatakan bahwa, advokat bertindak sesuai dengan permintaan klien, secara bebas mandiri, namun berdasarkan dengan perjanjian yang telah disepakati bersama. Seyogyanya setiap profesi advokat dalam menjalankan profesinya, patut memegang teguh kode etik profesi, dan patuh terhadap segala peraturan yang mengatur tentang profesinya. Karena berdasarkan dari terminologi profesi advokat, advokat dikenal sebagai konsultan hukum yang dapat memberi bantuan jasa di luar pengadilan, sehingga memiliki tingkat kerawanan yang tinggi terhadap aktifitas bentukan bisnis yang ilegal, terutama dalam hal aktiftas pencucian uang yang dapat ia kerjakan bersama dengan kliennya. 
Advokat sebagai gatekeeper dalam menciptakan praktik pencucian uang, dinilai oleh sebagian kriminal merupakan profesi yang sangat efektif dalam memanfaatkan keahliannya dalam praktik pencucian uang, dibandingkan dengan beberapa profesi tertentu lainnya. Dari penilaian tersebut, maka tidak sedikit pelaku kejahatan yang ingin melakukan pencucian uang, mengajak serta memanfaatkan profesi advokat dibandingkan dengan profesi lainnya dalam kegiatan ilegalnya tersebut. Memanfaatkan yang dimaksud dalam pernyataan tersebut adalah, campur tangan yang diperlukan dari profesi advokat dalam aktifitas pencucian uang, dengan cara berlindung pada aturan profesi advokat yang dapat menghindarkan pelaku kejahatan dari deteksi aparat penegak hukum dalam suatu proses tindak pidana pencucian uang. Tujuan utama dari segala aktifitas pencucian uang yang dilakukan oleh advokat tersebut, adalah keinginan untuk memperoleh keuntungan komersil, dari hasil kejahatan yang diperoleh oleh kliennya. Tujuan tersebut merupakan hubungan dari mutualisme antara pelaku kejahatan, dan advokat yang diminta dalam membantu aktifitas pencucian uang demi menghindarkan pelaku kejahatan, dari operasi tindak yang dilakukan oleh aparat penegak hukum terhadap hasil kejahatan yang telah diperolehnya.

Secara umum dapat disimpulkan dari pernyataan diatas bahwa profesi advokat sebagai gatekeeper diyakini oleh pelaku kejahatan sebagai profesi mengamankan, melegitimasi, atau mengaburkan sejumlah uang atau aset yang signifikan, dalam tujuan aktifitas pencucian uang. pemanfaatan yang dapat diperoleh dari profesi advokat adalah, pemahaman hukum yang hampir sama dari segala sisi keilmuan yang dimiliki aparat penegak hukum lainnya, sehingga dipercaya dapat membantu, dan melindungi para pelaku tindak pidana dari operasi yang dijalankan oleh aparat penegak hukum dalam pemberantasan tindak pidana pencucian uang. Jadi, profesi advokat sebagai gatekeeper, dewasa ini sudah menjadi suatu kebutuhan bagi para pelaku tindak pidana asal, untuk membantu dalam hal mengaburkan segala hasil perolehan tindak pidana, menjadi suatu aset atau penyemaran lainnya, semata-mata demi terlihat sahnya hasil tersebut di mata hukum. Misalnya tindak pidana asal yang dimaksud yaitu, para pelaku tindak 
pidana korupsi yang berusaha menyamarkan aset dengan melakukan aktfitas pencucian uang secara efektif agar terhindar dari jeratan hukum. ${ }^{15}$

Patut untuk diketahui bahwa, permasalahan terkait dengan profesi advokat sebagai gatekeeper, tidak hanya dibahas dalam skala nasional saja, melainkan juga di dunia internasional. Pada bulan Mei 2002, The Financial Action Task Force (selanjutnya disingkat menjadi FATF) menerbitkan "Gatekeeper Initiative" yang mengusulkan profesi hukum untuk ikut bekerjasama dengan lembaga aparat penegak hukum lainnya dalam memonitor pasar keuangan internasional. ${ }^{16}$ FATF adalah sebuah badan antar pemerintah yang bersifat independen, dalam mengembangkan, dan mempromosikan kebijakan untuk melindungi sistem keuangan global dalam upaya melawan tindak pidana pencucian uang dan terorisme. ${ }^{17}$

Formulasi yang dibentuk baik dalam skala nasional dan internasional seperti FTAFF di atas menegaskan bahwa dalam memberantas tindak pidana pencucian uang sungguh diperlukan adanya upaya yang sangat luar biasa. Mengingat pula bahwa tindak pidana pencucian uang merupakan tindak pidana lanjutan, yang patut juga ditelusuri oleh aparat penegak hukum terkait dengan hasil dari kejahatan awal yang telah diciptakan oleh pelaku kejahatan tersebut. Mengenal bahwa tindak pidana pencucian uang merupakan tindak pidana yang berlanjut, maka tindak pidana tersebut berlangsung dalam hal yang tingkatannya lebih tinggi dari tindak pidana asal pada umumnya. Karena alasan tersebut maka dipandang perlu bagi para kriminal untuk menggunakan jasa advokat sebagai kepanjangan tangan mereka dalam menciptakan suatu proses pencucian uang yang diharap maksimal. Seperti yang telah diketahui bersama, bahwa pencucian uang adalah suatu proses atau perbuatan yang bertujuan untuk menyembunyikan atau menyamarkan asal - usul uang, atau harta kekayaan yang diperoleh dari hasil tindak pidana, yang kemudian diubah menjadi

\footnotetext{
${ }^{15}$ ibid.[145].

${ }^{16}$ Erman Rajagukguk, ‘Advokat Dan Pemberantasan Korupsi’ Fakultas Hukum UI Jakarta.[333].

${ }^{17}$ FATF Report, Laundering the Proceeds of Corruption (FATF/OECD 2011).[Pendahuluan Informasi].
} 
harta kekayaan yang seolah-olah berasal dari kegiatan yang sah. ${ }^{18}$ Pemaknaan dari istilah hasil tindak pidana pada pengertian tersebut, mendiskripsikan tentang aset yang diperoleh dari tindak pidana, atau aset yang terkait dengan tindak pidana. Dari pernyataan tersebut, melahirkan suatu penalaran yang logis bahwa dibutuhkannya peran pendukung yang maksimal dalam menciptakan tindak pidana seserius itu.

Tindak pidana pencucian uang merupakan tindak pidana yang sangat susah untuk dikerjakan secara sendiri oleh satu orang individu, apalagi dilakukan oleh seseorang yang tidak dibekali oleh skill dan pengetahuan yang cukup dalam melakukan tindak pidana tersebut. Mengingat juga bahwa pencucian uang bukanlah suatu konsep yang sederhana, melainkan sangat rumit karena masalahnya begitu kompleks sehingga cukup sulit untuk menemukan perumusaan yang tepat dalam segala aktifitas yang terjadi dalam suatu tindak pidana pencucian uang.

Secara teoritis Toetik Rahayuningsih dan Soelistyowati menjelaskan lebih rinci mengenai tindak pidana pencucian uang yang merupakan tindak pidana lanjutan dan kaitannya dengan tindak pidana asal yang pada penjelasannya adalah sebagai berikut : Tindak pidana pencucian uang erat kaitannya dengan tindak pidana asal (predicate crime), sehingga dapat disimpulkan bahwa tindak pidana pencucian uang sebagai suatu tindak pidana lanjutan (follow up crime), tidak dapat berdiri sendiri, karena keberadaanya selalu didahului oleh tindak pidana asal. ${ }^{19}$ Mengenal bahwa tindak pidana pencucian uang tidak dapat berdiri sendiri, maka dipandang perlu adanya pencegahan terhadap segala aktifitas tindak pidana asal baik dalam kategori khusus, maupun tindak pidana yang dikategorikan dalam bentuk umum. Kategori khusus dalam tindak pidana asal yang berlanjut pada tindak pidana pencucian uang, memiliki sifat tindak pidana yang sama. Sifat yang dimaksud dalam tindak pidana khusus pada pembahasan ini adalah sifat kejahatannya yang sungguh dapat melahirkan dampak yang serius dan membutuhkan penanganan yang khusus (Extraordinary

\footnotetext{
${ }^{18}$ Adrian Sutedi, Hukum Perbankan : Suatu Tinjauan Pencucian Uang, Merger, Likuidasi, Dan Kepailitan (Sinar Grafika 2010). [19].

19 Toetik Rahayuningsih Soelistyowati, 'Model Kebijakan Perampasan Aset Hasil Tindak Pidana Perbankan Dalam Rangka Pencegahan Dan Pemberantasan Tindak Pidana Pencucian Uang', Laporan Akhir (Universitas Airlangga 2014).[16].
} 
crimes) dalam pencegahan dan pemberantasannya. Konsep Extraordinary crimes secara global dikenal sebagai kejahatan internasional yang bersifat luar biasa, dan memiliki dampak yang serius terhadap umat manusia, sehingga perlu dilakukan pencegahan yang bersifat luar biasa pula terhadap berbagai jenis kecaman yang dapat dihasilkan dari aktifitas kejahatan yang tergolong ke dalam ruang lingkup extraordinary crimes. Sedangkan ordinary crimes merupakan suatu kejahatan biasa, yang dampaknya tidak secara massive dirasakan oleh seluruh umat manusia. ${ }^{20}$ Tindak pidana pencucian uang merupakan tindak pidana yang tergolong ke dalam extraordinary crime (kejahatan yang luar biasa) sehingga, sangat diperlukan adanya penanggulangan yang besifat luar biasa (extra ordinary enforcement) terhadap tindak pidana ini, dan disertai dengan tindakan-tindakan luar biasa pula (extraordinary measures) kepada perkembangan tindak pidana tersebut. ${ }^{21}$ Secara umum maksud dari pelaku kejahatan dalam melakukan pencucian uang adalah, memindahkan atau menjauhkan pelaku kejahatan tersebut dari kejahatan yang menghasilkan proceeds of crime, memisahkan proceeds of crime dari kejahatan yang dilakukan, menikmati hasil kejahatan tanpa adanya kecurigaan kepada pelakunya, serta melakukan reinvestasi hasil kejahatan untuk aksi kejahatan selanjutnya ke dalam bisnis yang sah. ${ }^{22}$ Di dunia kejahatan pencucian uang terdapat dua kelompok pelaku yaitu kelompok yang berkaitan langsung dengan predicate crime yang disebut principle violater, dan kelompok kedua yang sama sekali tidak berkaitan langsung dengan predicate crime, misalnya yaitu profesi advokat. ${ }^{23}$

Seyogyanya para profesi advokat, lebih menekankan prinsip kebenaran saat membela kepentingan kliennya. Hal ini dimaksudkan agar, tidak adanya salah perilaku dari para profesi advokat dalam mewujudkan keadilan bagi masyarakat

\footnotetext{
${ }^{20}$ Joko Setiyono, 'Pertanggungjawaban Komando (Command Responsibility) Dalam Pelanggaran Ham Berat (Studi Kasus Kejahatan Terhadap Kemanusiaan)', Disertasi (Program Pasca Sarjana, Doktor Ilmu Hukum Universitas Diponegoro 2010).[21].

${ }^{21}$ Hiyatullah Syaifullah Yophi, Sunarmi, Kusnadi Al, 'Tinjauan Yuridis Pembuktian Terbalik Dalam Tindak Pidana Pencucian Uang', Makalah.[1].

${ }_{22}$ Yunus Husein, 'Pencegahan Dan Pemberantasan Tindak Pidana Pencucian Uang Di Indonesia', Makalah tentang 'Tindak Pidana Pencucian Uang' (Financial Club 2014). [8].

${ }^{23}$ AM Mujahidin, 'Kriminalisasi Pencucian Uang Dan Strategi Pemberantasannya', Makalah.[7].
} 
umum. Perilaku tersebut tentunya, dilandasi dengan bercermin pada aturan hukum yang mengatur tentang profesinya, dan aturan tersebut wajib dijunjung tinggi oleh advokat dalam menjalankan profesinya. Tujuannya adalah, membangun citra yang baik terhadap profesi advokat dan menciptakan kinerja yang seharusnya dilakukan oleh para profesi advokat yang berperan sebagai bagian dari profesi hukum.

\section{Sanksi yang Dapat Dikenakan Terhadap Advokat Sebagai Gatekeeper dalam Tindak Pidana Pencucian Uang}

Pengenaan gelar gatekeeper terhadap profesi advokat, merupakan bagian dari penyebutan terhadap kriminal advokat yang menyalahi aturan hukum, dengan memanfaatkan profesinya demi keuntungan pribadi atau pihak tertentu dengan cara yang tidak halal. Aktifitas kejahatan yang rentan dilakukan oleh profesi advokat dimaksud adalah, tindak pidana pencucian uang yang dilakukan secara bersamasama dengan kliennya.

Menanggapi permasalahan di atas, maka dipandang perlu untuk membentuk suatu regulasi yang menuntut profesi advokat, sebagai pendukung dari upaya pemerintah untuk mencegah dan memberantas aktifitas tindak pidana pencucian uang. Regulasi yang dimaksud tersebut, telah disahkan oleh pemerintah, sehingga berlaku bagi profesi advokat dan profesi lainnya, yang karena profesinya dinilai rentan menjadi gatekeeper dalam kasus tindak pidana pencucian uang. Regulasi yang dimaksud adalah PP No. 43 Tahun 2015.

PP No. 43 Tahun 2015, menetapkan profesi advokat sebagai salah satu bagian dari pihak pelapor yang wajib melaporkan adanya transaksi mencurigakan kepada PPATK. Hal tersebut, tidak hanya merupakan kewajiban dari profesi advokat sebagai pihak pelapor, namun juga merupakan suatu kewajiban yang melekat dari profesi advokat sebagai bagian dari profesi hukum. Kewajiban profesi advokat sebagai pihak pelapor dalam upaya pencegahan dan pemberantasan tindak pidana pencucian uang, melahirkan suatu konsekuensi sanksi terhadap profesi advokat, jika tidak mematuhi kewajibannya sebagai pihak pelapor dalam tindak pidana pencucian uang. 
PP No 43 Tahun 2015 memang tidak mencantumkan pengenaan sanksi terhadap pihak pelapor yang tidak melaporkan tindak pidana pencucian uang kepada lembaga PPATK, namun pada Pasal 1 angka 9 PP No 43 Tahun 2015, menyinggung tentang pengenaan sanksi kepada pihak pelapor yang tidak mematuhi aturan terkait dengan kewajiban melapor. Pasal 1 angka 9 PP No 43 Tahun 2015 yang berbunyi: Lembaga Pengawas dan Pengatur adalah lembaga yang memiliki kewenangan pengawasan, pengaturan, dan /atau pengenaan sanksi terhadap Pihak Pelapor. Pada aturan tersebut memang tidak dijelaskan secara eksplisit perihal pengenaan sanksi, namun dari isi pasal tersebut, secara tidak langsung memberikan penegasan bahwa, akan ada sanksi terhadap pihak pelapor yang tidak mematuhi kewajibannya sebagai pihak pelapor dalam tindak pidana pencucian uang. Jadi, kesimpulan yang dapat dipahami dari ketentuan tersebut adalah, jika diketahui oleh PPATK adanya kerjasama atau pembiaran dari pihak pelapor (advokat) terhadap pelaku tindak pidana pencucian uang, maka akan ada pengenaan sanksi terhadap pihak pelapor tersebut. Sanksi yang akan dikenakan pada advokat tersebut, tentu sesuai dengan aturan yang mengatur sanksi pidana terkait dengan kejahatan tindak pidana pencucian uang.

Peraturan yang mengatur perihal sanksi pidana terkait dengan kejahatan tindak pidana pencucian uang adalah UU No. 8 Tahun 2010. Mengingat bahwa advokat dalam pembahasan sebelumnya merupakan profesi yang dinilai sebagai profesi yang memiliki akses luar biasa dalam birokrasi dan hukum, sehingga jika ia melakukan suatu tindak pidana yang berkaitan dengan tindak pidana pencucian uang dapat dengan mudah memanipulasi adanya resiko pelacakan dari pemirintah maupun aparat penegak hukum. Dan untuk kemungkinan tindak pidana yang dapat dilakukannya terkait tindak pidana pencucian uang adalah tindak pidana yang diatur pada Pasal 3, 4, 5, dan 10 UU No. 8/2010. Jadi kepada para profesi advokat yang melakukan aktifitas pencucian uang, baik dengan cara mentransfer, membelanjakan, hingga membawa ke luar negeri harta kekayaan dari kliennya, dan telah diketahui olehnya hal tersebut merupakan suatu hasil perolehan dari tindak pidana, maka advokat tersebut dapat dikenakan sanksi pidana sesuai dengan ketentuan pada Pasal 3 UU No. 8/2010, yang bunyi pasalnya adalah sebagai berikut: 
"Setiap Orang yang menempatkan, mentransfer, mengalihkan, membelanjakan, membayarkan, menghibahkan, menitipkan, membawa ke luar negeri, mengubah bentuk, menukarkan dengan mata uang atau surat berharga atau perbuatan lain atas Harta Kekayaan yang diketahuinya atau patut diduganya merupakan hasil tindak pidana sebagaimana dimaksud dalam Pasal 2 ayat 1 dengan tujuan menyembunyikan atau menyamarkan asal usul Harta Kekayaan dipidana karena tindak pidana Pencucian Uang dengan pidana penjara paling lama 20 (dua puluh) tahun dan denda paling banyak Rp 10.000.000.000,00 (sepuluh miliar rupiah)".

Selanjutnya, kepada para profesi advokat yang melakukan aktifitas pencucian uang, dengan cara menyembunyikan, atau menyamarkan asal usul harta kekayaan kliennya, dan diketahui olehnya merupakan hasil dari perolehan tindak pidana, maka advokat tersebut dapat dikenakan sanksi pidana sesuai dengan ketentuan pada Pasal 4 UU No. 8/2010, yang bunyi pasalnya adalah sebagai berikut:

"Setiap Orang yang menyembunyikan atau menyamarkan asal usul, sumber, lokasi, peruntukan, pengalihan hak-hak, atau kepemilikan yang sebenarnya atas Harta Kekayaan yang diketahuinya atau patut diduganya merupakan hasil tindak pidana sebagaimana dimaksud dalam Pasal 2 ayat 1 dipidana karena tindak pidana Pencucian Uang dengan pidana penjara paling lama 20 (dua puluh) tahun dan denda paling banyak Rp 5.000.000.000,00 (lima miliar rupiah)”.

Selebihnya, kepada para profesi advokat yang melakukan aktifitas tindak pidana pencucian uang, dengan cara menerima atau menguasai penempatan terhadap asal usul harta kekayaan kliennya, yang diketahui olehnya merupakan hasil dari suatu perolehan tindak pidana, maka advokat tersebut dapat dikenakan sanksi pidana sesuai ketentuan pada Pasal 5 UU No. 8/2010, yang bunyi pasalnya adalah sebagai berikut:

“(1) Setiap Orang yang menerima atau menguasai penempatan, pentransferan, pembayaran, hibah, sumbangan, penitipan, penukaran, atau menggunakan Harta Kekayaan yang diketahuinya atau patut diduganya merupakan hasil tindak pidana sebagaimana dimaksud dalam Pasal 2 ayat 1 dipidana dengan pidana penjara paling lama 5 (lima) tahun dan denda paling banyak Rp 1.000.000.000,00 (satu miliar rupiah). (2) Ketentuan sebagaimana dimaksud pada ayat 1 tidak berlaku bagi Pihak Pelapor yang melaksanakan kewajiban pelaporan sebagaimana diatur dalam Undang-Undang ini”.

Perolehan tindak pidana, maka advokat tersebut dapat dikenakan sanksi pidana sesuai ketentuan pada Pasal 5 UU No. 8/2010, yang bunyi pasalnya adalah sebagai berikut:

“(1) Setiap Orang yang menerima atau menguasai penempatan, pentransferan, pembayaran, hibah, sumbangan, penitipan, penukaran, atau menggunakan Harta Kekayaan yang diketahuinya atau patut diduganya merupakan hasil 
tindak pidana sebagaimana dimaksud dalam Pasal 2 ayat 1 dipidana dengan pidana penjara paling lama 5 (lima) tahun dan denda $\mathrm{p}$ aling banyak Rp 1.000.000.000,00 (satu miliar rupiah). (2) Ketentuan sebagaimana dimaksud pada ayat 1 tidak berlaku bagi Pihak Pelapor yang melaksanakan kewajiban pelaporan sebagaimana diatur dalam Undang-Undang ini”.

Sedangkan, kepada para profesi advokat yang turut serta melakukan aktifitas tindak pidana pencucian uang bersama-sama dengan kliennya, dapat dikenakan sanksi pidana sesuai dengan ketentuan pada Pasal 10 UU No. 8/2010, yang bunyi pasalnya adalah sebagai berikut:

"Setiap Orang yang berada di dalam atau di luar wilayah Negara Kesatuan Republik Indonesia yang turut serta melakukan percobaan, pembantuan, atau Permufakatan Jahat untuk melakukan tindak pidana Pencucian Uang dipidana dengan pidana yang sama sebagaimana dimaksud dalam Pasal 3, Pasal 4, dan Pasal 5".

Macam-macam penjatuhan sanksi pidana terhadap advokat di atas, merupakan kategori penegasan terhadap bentuk tindakan apa saja yang telah dilakukan oleh advokat dalam melakukan aktifitas pencucian uang bersama - sama dengan kliennya. Kata penegasan dalam pernyataan tersebut, merupakan rumusan delik terkait dengan tindak pidana pencucian uang yang dilakukan oleh advokat bersama dengan kliennya. Jadi, advokat dalam melakukan aktifitas pencucian uang, memiliki cara-cara yang berbeda, dan setiap cara yang dilaksanakan merupakan hal yang tidak dibenarkan oleh UU No. 8 Tahun 2010. Sehingga telah selesainya perbuatan tersebut atau masih dalam pelaksanaan terkait dengan aktifitas pencucian uang dimaksud, rangkaian dari perbuatan yang dilakukan tidak dibenarkan oleh peraturan perundang-undangan terkait.

Membahas mengenai penjatuhan sanksi, bahwa terdapat sanksi lain, selain dari penjatuhan sanksi pidana terhadap advokat yang melakukan aktifitas pencucian uang. Sanksi lain yang dimaksud adalah, diberhentikannya advokat dari profesinya secara tetap. Sanksi tersebut di atur secara tegas dalam Pasal 10 ayat 1 huruf b UU No. 18/2003, yang pada pasalnya berbunyi sebagai berikut: (1) Advokat berhenti atau dapat diberhentikan dari profesinya secara tetap karena alasan: b. dijatuhi pidana yang telah mempunyai kekuatan hukum tetap, karena melakukan tindak pidana yang diancam dengan hukuman empat tahun atau lebih. 
Berdasarkan dari isi ketentuan di atas, maka hal yang dapat disimpulkan secara praktis yaitu UU No. 18/2003, menyetujui adanya penjatuhan sanksi pidana terhadap advokat, yang terlibat dalam suatu tindak pidana tertentu, terutama kepada advokat yang dikenakan sanksi pidana terkait dengan tindak pidana yang ancamannya adalah empat tahun atau lebih. Penjelasan tersebut secara tidak langsung, menegaskan bahwa kepada seluruh penyandang profesi advokat, untuk kesediaanya agar mentaati segala peraturan yang telah mencantumkan kewajiban kepada profesinya, terutama terkait dengan upaya pemerintah dalam mencegah dan memberantas tindak pidana tertentu. Sesungguhnya pernyataan tersebut, merupakan suatu impian bersama, dengan bantuan dari advokat untuk membebaskan negara dari segala aktifitas tindak pidana tertentu, terutama tindak pidana pencucian uang yang sifatnya extraordinary crime.

\section{Kesimpulan}

Upaya dalam mewujudkan keadilan dan mencegah aktifitas kriminal, merupakan sebagian dari kewajiban yang harus dilaksanakan oleh para penyandang profesi hukum. Jadi, mewujudkan keadilan dan mencegah aktifitas kriminal merupakan hal umum yang patut dilaksanakan oleh para profesi hukum, maka para penyandang profesi advokat yang posisinya telah dikualifikasikan juga sebagai profesi hukum, wajib untuk mewujudkan adanya keadilan dan mencegah aktifitas kriminal, apalagi terhadap tindak pidana serius seperti pencucian uang. Para penyandang profesi advokat tidak wajib untuk memberikan bantuan hukum kepada para calon klien yang membutuhkan jasa dari profesinya tersebut, apalagi untuk bekerjasama dalam hal membantu atau melakukan suatu rangkaian tindak pidana yang bertentangan dengan hati nuraninya. Namun patut untuk dipahami, bahwa yang dimaksud dalam pesan penolakan dimaksud adalah, membantu para klien yang memiliki niat jahat atau merancang suatu aktifitas kriminal yang sifatnya massive atau segala macam kegiatan yang dapat merugikan masyarakat secara umum. Misalnya tindak pidana pencucian uang, dan patut untuk dimengerti, bahwa tidak ada pertentangan aturan terkait dengan segala bentuk perlindungan 
terhadap advokat yang tercantum dalam UU No. 18/2003 dengan kewajiban advokat sebagai pihak pelapor yang tercantum pada PP No. 43 Tahun 2015, karena substansi pembahasannya itu berbeda, jadi terdapat adanya pengecualian dalam bahasan tersebut, bukan merupakan suatu penyimpangan. Kepada para advokatyang melanggar ketentuan dalam PP No. 43 Tahun 2015 dapat dikenakan sanksi oleh PPATK sebagai lembaga penanggung jawab terkait pelanggaran yang diciptakan oleh advokat dalam peraturan terkait. Namun untuk penjatuhan sanksi pidana, terkait kerja sama atau segala tindakan yang berkaitan dengan tindak pidana pencucian uang, maka advokat yang bersalah akan dikenakan sanksi pidana sesuai dengan aturan yang mengatur jenis pidana tersebut (UU No. 8/2010).

\section{Daftar Bacaan}

\section{Buku}

Eddyono SW, Mengurai Implementasi Dan Tantangan Anti Pencucian Uang Di Indonesia (ICJR (Institute for Criminal Justice Reform) 2015).

FATF Report, Laundering the Proceeds of Corruption (FATF/OECD 2011).

Keuangan, 'Pusat Pelaporan Dan Analisis Transaksi', Laporan Tahunan 2014 (PPATK (Pusat Pelaporan dan Analisis Transaksi Keuangan) 2015).

Rahayuningsih T, 'Perampasan Aset Hasil Tindak Pidana Perbankan Dalam Rangka Pemberantasan Tindak Pidana Pencucian Uang', Laporan Penelitian (2014).

Rajagukguk E, ‘Advokat Dan Pemberantasan Korupsi’ Fakultas Hukum UI Jakarta Sinaga VH, Dasar-Dasar Profesi Advokat (Erlangga 2011).

Sutedi A, Hukum Perbankan : Suatu Tinjauan Pencucian Uang, Merger, Likuidasi, Dan Kepailitan (Sinar Grafika 2010).

Utama P, Memahami Asset Recovery \& Gatekeeper, Jakarta, Indonesian Legal Roundtable (Indonesian Legal Roundtable 2013).

\section{Jurnal}

M Arief Amrullah, 'Pencucian Uang Dan Kejahatan Terorganisir' (2003) 10 Jurnal Hukum. 
Lumbun TG, 'Peran Advokat Sebagai Penegak Hukum Menghadapai Transnational Crimes Di Era Globalisasi' (2004) IV No. 1 Law Review Fakultas Hukum Universitas Pelita Harapan.

\section{Makalah}

Husein Y, 'Pencegahan Dan Pemberantasan Tindak Pidana Pencucian Uang Di Indonesia', Makalah tentang 'Tindak Pidana Pencucian Uang' (Financial Club 2014).

Mujahidin A, 'Kriminalisasi Pencucian Uang Dan Strategi Pemberantasannya', Makalah.

Recovery, 'International Centre for Asset. Tracing Stolen Assets: A Practitioner's Handbook, Basel Institute on Governance', Makalah (International Centre for Asset Recovery Steinenring 2009).

Nurudin A, 'Revitalisasi Keberpihakkan Profesi Advokat Terhadap Klien Yang Tidak Mampu', Makalah (Kantor Konsultasi Hukum Agus Nurudin).

\section{Karya Ilmiah}

P. Mathita Ranti Hapsari, 'Kebijakan Formulasi Hukum Pidana Dalam Undang Undang Tindak Pidana Pencucian Uang (Money Laundering)', Tesis (Bidang Kajian Hukum dan Sistem Peradilan Pidana Program Magister Ilmu Hukum Universitas Diponegoro).

Setiyono J, 'Pertanggungjawaban Komando (Command Responsibility) Dalam Pelanggaran Ham Berat (Studi Kasus Kejahatan Terhadap Kemanusiaan)', Disertasi (Program Pasca Sarjana, Doktor Ilmu Hukum Universitas Diponegoro 2010).

Soelistyowati TR, 'Model Kebijakan Perampasan Aset Hasil Tindak Pidana Perbankan Dalam Rangka Pencegahan Dan Pemberantasan Tindak Pidana Pencucian Uang', Laporan Akhir (Universitas Airlangga 2014)

\section{Perundang-undangan}

Undang-Undang Nomor 18 Tahun 2003 Tentang Advokat.

Undang-Undang Nomor 5 Tahun 2009 Tentang Pengesahan United Nations Convention Againts Transnational Organized Crime (Konvensi Perserikatan Bangsa-Bangsa Menentang Tindak Pidana Transnasional yang Terorganisasi). Undang-Undang Nomor 8 Tahun 2010 tentang Pencegahan dan Pemberantasan 
Tindak Pidana Pencucian Uang.

Peraturan Pemerintah Nomor 43 Tahun 2015 Tentang Pihak Pelapor dalam Pencegahan dan Pemberantasan Tindak Pidana Pencucian Uang.

Peraturan Pemerintah Nomor 2 Tahun 2016 Tentang Tata Cara Penyampaian dan Informasi oleh Instansi Pemerintah dan / atau Lembaga Swasta dalam Pencegahan dan Pemberantasan Tindak Pidana Pencucian Uang.

HOW TO CITE: Rendy Ardy, 'Pertanggungjawaban Advokat Sebagai Gatekeeper Dalam Kaitannya Dengan Tindak Pidana Pencucian Uang' (2018) Vol. 1 No. 2 Media Iuris. 